\title{
Komunikasi Interpersonal Keluarga Kristen Memasuki Era 4.0
}

\author{
Naomi Sampe \\ Sekolah Tinggi Agama Kristen Negeri Toraja, Tana Toraja, Sulawesi Selatan \\ naomisampe23@gmail.com
}

\begin{abstract}
This article is a study to show that in these days, we all are living in the time that named industry revolution 4.0, which's all communication tool are connected and communicate each other to make smart decisions without human role. As we see now that our world is borderless. The communication is rapidly informed, and we could feel, hear, see clearly that such as sophisticated so as every event in "the edge of this earth" could be known to us almost in the same time while it happened. The result of this research has found that this revolution has totaly change our interpersonal communication way. This study also suggest that in delivery their mission, christian and the church leader ought to recreate and transform their duty to serve. The most basicly community of the churc is family, thats why this research is put a special notice to the interpersonal communication. This is the strategic point to form christian generation to have their own identity and assist them in faith grow as the child of God.
\end{abstract}

Keyword: communication; interpersonal communication; era of 4.0; Christian familiy

\begin{abstract}
Abstrak: Tulisan ini merupakan studi yang hendak menyajikan bahwa kita semua sudah berada dalam budaya kehidupan yang disebut Era 4.0, di mana semua alat komunikasi sudah terjaring satu sama lain dan ternyata telah sanggup mencipta sendiri keputusan cerdas dan seringkali tanpa peran atau bantuan manusia lagi. Sekarang yang disaksikan adalah dunia yang tanpa batas. Hasil dari penelitian ini menemukan bahwa era sekarang telah mengubah cara kita berkomunikasi secara interpersonal. Tulisan ini juga hendak menggagas bahwa dalam rangka melayankan misinya, kekristenan dan para pemimpin gereja seharusnya mencipta ulang dan atau mentransformasi tugas pelayanan mereka. Dalam hal ini, komunitas basis dari gereja adalah keluarga, itu sebabnya penelitian ini memberi tekanan khusus pada komunikasi interpersonal; karena ini adalah pintu masuk yang strategis untuk membentuk generasi kristen agara mereka memliki identitas diri dan mendampingi mereka dalam bertumbuh secara iman sebagai anak Tuhan.
\end{abstract}

Kata kunci: era 4.0; komunikasi; komunikasi interpersonal; keluarga Kristen

\begin{tabular}{llll}
\hline Article History : & Received: 11-03-2019 & Revised: 05-04-2019 Accepted: 13-06-2019
\end{tabular}

\section{Pendahuluan}

Perubahan metode berkomunikasi dalam dekade terakhir ini, mengalami peningkatan yang sangat signifikan. Orang mulai meninggalkan cara berkomunikasi secara langsung dalam arti hadir secara fisik dalam satu tempat dan waktu. Dan lebih memilih berkomunikasi secara maya tanpa perjumpaan secara fisik. Komunikasi era sekarang dikenal 
sebagai era komunikasi dengan konektivitas tinggi, serta melampaui realitas, yang juga sering disebut revolusi digital. ${ }^{1}$ Perubahan cara berkomunikasi saat ini adalah hal yang wajar oleh karena itu tidak mendapat perhatian dari keluarga, gereja dan masyarakat. Padahal dalam kenyataannya berbagai problematika dalam keluarga Kristen muncul karena ketidaksiapan menghadapi perubahan cara berkomunikasi di era digital ini. Sebagai contoh faktual, fenomena phubbing dalam keluarga di meja makan, anak-anak yang minta makanan kepada orangtua melalui sms dari dalam ruang kamarnya. Dapat dilihat bahwa tidak sedikit permasalahan yang timbul dalam keluarga sebenarnya berakar dari minimnya komunikasi dalam kasih antara orangtua dan anak, maupun antara suami dan istri. Dapat juga dikatakan bahwa motif dari problem tersebut sebenarnya dapat diselesaikan melalui komunikasi yang diwujudkan melalui ketela-danan. ${ }^{2}$ Jika pola relasi sudah terganggu maka kemungkinan besar akan ada masalah. Penggunaan gawai dan aplikasi digital secara berlebihan selanjutnya menyita waktu keluarga untuk duduk bersama dan bercakap-cakap secara langsung, lalu anak-anak menjadi antisosial, orangtua membiarkan saja hal ini terjadi, abai maka lama-kelamaan masalah komunikasi justru bertambah kompleks. Semua persoalan di dunia ini dimulai dari keluarga; tidak sulit melacak kebenaran ini. Jika ada anak yang memiliki masalah perilaku di sekolah, seringkali itu karena masalah di rumah. ${ }^{3}$ Masalah tidak selesai dengan sendirinya malah sebaliknya bisa juga makin berlapis dan makin membesar. Oleh karena itu, masalah antisosial dari seorang anak akan terbawa sampai masa dewasanya. ${ }^{4}$

Problematika komunikasi bukan hanya sekadar terfokus pada produk artifisial, tetapi masalah yang lebih substantif ada dalam dinamika interaksional (yang justru tidak terlihat kasat mata/intangible). Persoalan antaranggota keluarga bukan masalah yang hanya terbatas dalam lingkup keluarga saja, karena ternyata dapat dilacak bahwa masalah-masalah dalam masyarakat sejatinya berakar pada masalah dalam keluarga sebagai lembaga sosial terkecil dari masyarakat itu sendiri. ${ }^{5}$ Dengan kata lain, masyarakat yang sakit dipastikan dilatarbelakangi oleh fakta unsur-unsur keluarga yang sakit pula.

Pada hakikatnya, keluarga amat membutuhkan hubungan yang saling mengasihi, saling menghargai, dan saling berbagi. Oleh karena hal ini merupakan kebutuhan kekal dari keluarga maka kecakapan berkomunikasi interpersonal merupakan prasyarat yang diperlkan dalam keluarga. Dalam Kamus Besar Bahasa Indonesia, keluarga diartikan

${ }^{1}$ AG. Eka Wenats Wuryantai, “Digitalisasi Masyarakat: Menilik Kekuatan Dan Kelemahan Dinamika Era Informasi Digital Dan Masyarakat Informasi," Jurnal ILMU KOMUNIKASI 1, no. 2 (November 27, 2013), accessed August 31, 2017, http://ojs.uajy.ac.id/index.php/jik/article/view/163.

2Rannu Sanderan, Exemplary, Menemukan Kunci Pendidikan Iman bagi Anak dalam Keluarga dan Pembelajaran Agama di Sekolah (Jurnal Arrang STAKN Toraja, 2016)

3Andrew Brake, Hidup Bijak di Dunia Bodoh, Mengali Sumber Hikmat Sejati dari Kitab Amsal, (Bandung: Kalam Hidup, 2015), 86

4Ibid.

5Ibid. 
sebagai kaum, yakni sanak saudara yang terdiri dari ibu, bapak dengan anak-anaknya atau orang yang tinggal dalam satu rumah, ${ }^{6}$ selanjutnya secara antropologi dikenal istilah 'keluarga batih' yakni keluarga yang hanya terdiri: suami-istri dan anak atau suami (atau istri) dan anak yang juga sering disebut keluarga inti atau nuclear family. Sedangkan yang lebih luas disebut extended family yakni keluarga yang tidak hanya terdiri dari suami, istri dan anak, juga termasuk adik, kakak ipar, keponakan, dan/atau semua orang yang tinggal dalam satu rumah. ${ }^{7}$ Era industri 4.0 sekarang ini turut membentuk ulang pola komunikasi dari keluarga ini, baik kedekatan maupun dinamika dan interaksi mereka.

Sejatinya pola komunikasi dalam keluarga Kristen dijiwai oleh cinta kasih, sehingga secara ideal, tidak akan ada permasalahan atau konflik. Tetapi realitas menunjukkan bahwa cukup banyak keluarga Kristen yang diterpa masalah, entah masalah orangtua dengan anak, atau persoalan suami dan isteri pun dalam rumpun keluarga yang lebih besar. Penelitian lain yang sebelumnya telah membahas wacana sehubungan domain topik ini berjudul Aktualisasi Pelayanan Karunia di Era Digital, namun orientasinya tulisan tersebut agar gereja tidak boleh apatis atau gagal memanfaatkan peluang dari kemajuan tekonologi digital demi kemajuan pekerjaan Tuhan. ${ }^{8}$

Tulisan ini hendak menegaskan bahwa komunikasi merupakan dinamika yang terus menjadi dan berubah. Gereja, pemimpin serta umat kristiani seyogianya memberi perhatian secara terus menerus terhadap realita perubahan budaya sekarang ini. Basis gereja adalah keluarga, oleh karena itu masalah antisosial dan individualisme sebagai salah satu akibat dari revolusi industri juga merupakan persoalan gereja. Realias menunjukkan bahwa problem transmisi informasi (entah valid atau hoax) yang terjadi sangat cepat perlu mendapat perhatian khusus dari orangtua, gereja dan para pemimpin kristen.

Urgensi penelitian ini berhubungan dengan gempuran informasi yang dapat mendistraksi kecakapan anak dalam menentukan pilihan bijak sehingga menjadi persoalan tersendiri yang perlu dipikirkan dalam melihat perkembangan otonomi diri seorang anak. Maka keluarga, gereja, pemimpin kristen serta komunitas parachurch merupakan stakeholder yang memiliki peran penting menanamkan nilai dan memperlengkapi anggotanya dengan kecakapan menyaring informasi dengan bijak. Seorang anak perlu dididik memilah dan memilih dalam rangka mengambil keputusan bijaksana melalui latihan dan proses komunikasi interpersonal. Oleh karena itu, pembudayaan komunikasi interpersonal dalam keluarga hendaknya menjadi sasaran serta kebutuhan penguatan dari segenap pemangku kepentingan.

${ }_{6}^{6}$ Departemen Pendidikan dan Kebudayaan., Kamus Besar Bahasa Indonesia,. 471

${ }^{7}$ Diana Ariswanti Triningtyas, Sex Education, (Magetan: CV. AE Media Grafika, 2017), 54-55

${ }^{8}$ Harls Evan R. Siahaan, "Aktualisasi Pelayanan Karunia Di Era Digital," EPIGRAPHE: Jurnal Teologi dan Pelayanan Kristiani 1, no. 1 (2017): 23-38, www.stttorsina.ac.id/jurnal/index.php/epigraphe. 


\section{Metode Penelitian}

Penelitian ini memiliki sifat yang mengkaji konten dari berbagai data dan informasi tulisan, citra dan/atau grafik yang terpublikasi melalui media cetak, serta audio visual, maka metode yang hendak dipakai adalah analisa konten. Di samping itu, diskursus dari topik penelitian ini adalah bidang ilmu komunikasi maka analisa tersebut memang dianggap patut menjadi metode penelitian.

Menurut pencetus analisis ini yakni Klaus Krippendorf, mengatakan:

The intellectual roots of content analysis, however, can be traced far back in human history, to the beginning of the conscious use of symbols and voice, especially writing. This conscious use, which replaced the magical use of language, has been shaped by the ancient disciplines of philosophy, rhetoric, and cryptography. It has also spawned religious inquisitions and political censorship on the part of ruling establishments. Today, symbolic phenomena are institutionalized in art, literature, education, and the mass media, including the Internet. ${ }^{9}$

Dengan demikian, penelitian ini diharapkan dapat memberi manfaat terhadap pengembangan teoretis sehubungan dengan patron komunikasi interpersonal dalam keluarga Kristen dengan mengacu pada berbagai perkembangan sejarah manusia.

Sejak dahulu hingga kini kesadaran pada pentingnya penggunaan simbol (ikon) serta suara dan tulisan telah menunjukkan eksistensinya hingga era 4.0 sekarang ini. Tahapan penelitian yang hendak ditempuh adalah pertama menkonstruksi problem realita dalam masyarakat untuk mencari jawabannya secara pustaka. Kedua, mengumpulkan data-data dari literatur online (ebook dan jurnal) dan buku-buku hardcopy tentang topik komunikasi interpersonal keluarga Kristen dan pengaruh revolusi industri 4.0 terhadap komunikasi dalam keluarga. Selanjutnya data-data tersebut dikelompokkan sesui kategori yang dibutuhkan berdasarkan sistematika penulisan. Ketiga peneliti melakukan analisis dan pemaknaan terhadap uraian data tersebut (das sein) dan dikomparasi dengan realita persoalan dalam komunikasi keluarga Kristen di era 4.0 (das sollen). Sebagai bagian akhir dari penelitian ini, maka peneliti memberi kesimpulan terhadap jawaban terhadap persoalan yang diangkat dalam penelitian ini untuk meneliti tujuan penelitian.

\section{Pembahasan}

Keluarga terdiri atas mereka yang memunyai hubungan darah dan/atau tinggal bersama-sama dalam satu rumah, yang mana di dalamnya pertama-tama ada suami-istri yang dipersatukan oleh ikatan perkawinan. Rasul Paulus mendeskripsikan pola hubungan cinta kasih antara suami dan istri dalam suratnya kepada jemaat di Efesus, bagaikan hubungan antara Kristus dengan jemaat, dimana sang suami yang adalah kepala istri sama seperti Kristus adalah kepala jemaat, harus mengasihi istrinya dan

${ }^{9}$ Mack Shelley and Klaus Krippendorff, "Content Analysis: An Introduction to Its Methodology.," Journal of the American Statistical Association 79, no. 385 (March 1984): 240. 
begitupun sebaliknya sang istri harus tunduk kepada suaminya. Itu sebabnya hubungan keluarga itu kudus adanya (Ef. 5:22-25).

Kemudian, pola komunikasi antara orangtua dengan anak-anaknya juga diungkapkan rasul Paulus dalam kitab Efesus 6:1-4, dimana anak-anak harus menaati dan menghormati orang tua di dalam Tuhan, dan meskipun era telah berubah namun Efesus 4 tersebut menjadi salah satu dasar teologis untuk menekankan komunikasi interpersonal adalah orangtua harus senantiasa mendidik mereka berdasarkan ajaran dan nasihat dari Tuhan: "Hai anak-anak, taatilah orang tuamu di dalam Tuhan, karena haruslah demikian. Hormatilah ayahmu dan ibumu -- ini adalah suatu perintah yang penting, seperti yang nyata dari janji ini: supaya kamu berbahagia dan panjang umurmu di bumi. Dan kamu, bapa-bapa, janganlah bangkitkan amarah di dalam hati anakanakmu, tetapi didiklah mereka di dalam ajaran dan nasihat Tuhan." Hal ini pun senada dengan perintah yang disampaikan Tuhan Allah kepada orang Israel dalam Ulangan 6:5, "Kasihilah TUHAN, Allahmu, dengan segenap hatimu dan dengan segenap jiwamu dan dengan segenap kekuatanmu." Perintah ini harus diajarkan secara berulang-ulang dalam kehidupan keluarga mereka, yaitu kepada anak-anak dan seluruh anggota keluarga mereka, dengan sendirinya budaya komunikasi interpersonal dalam keluarga dapat senantiasa bertumbuh.

Dalam kehidupan anak-anak pun sebagaimana diungkapkan rasul Paulus, mereka seharusnya menjadi anak-anak terang yang hidup di dalam cinta kasih Kristus (Ef. 5:121). Implikasinya, komunikasi interpersonal yang dibudayakan keluarga Kristen diharapkan justru memiliki dampak sosial secara lebih luas dan berkelanjutan, dengan corak dan keunikan karakter kristiani sebagai identitas dan kebanggaan dalam era digital sekarang ini. Jadi hubungan cinta kasih yang terjalin di dalam kehidupan keluarga Kristen, semuanya bertolak dari cinta kasih Kristus yang telah rela menyerahkan diriNya untuk menyelamatkan manusia dari dosa. Sehingga terjalinnya hubungan cinta kasih antarsesama anggota keluarga merupakan cerminan dari kasih Kristus. Cinta kasih Kristus adalah dasar kehidupan keluarga Kristen, yang dinyatakan lewat komunikasi interpersonal dengan sesama anggota keluarga.

David W. Johnson salah seorang pakar komunikasi dalam bukunya Reaching Out. Interpersonal Effectiveness and Self-Actualization menekankan beberapa point mengenai pentingnya komunikasi antarpribadi yakni dapat membantu perkembangan intelektual dan sosial seseorang. Pokok-pokok pikiran David selanjutnya disitir oleh Dr. A. Supratiknya untuk menyatakan bahwa komunikasi antarpribadi yang sehat akan menghasilkan kesehatan mental yang baik. Generasi baby boomers, X, Y, Z dan alpha sama-sama mengalami perkembangan sejak masa bayi sampai masa dewasa. Kelompokkelompok ini mengawali pertumbuhan dalam pola yang sama yakni kebergantungan pada pada orang lain, sejak kontak komunikasi intensif dengan ibu pada masa bayi lalu kebergantungan pada komunikasi yang lebih luas sehubungan pertambahan usia. 
Persamaan kelompok generasi yang prinsipil adalah perkembangan intelektual dan sosial mereka amat ditentukan oleh kualitas komunikasi kita dengan orang lain itu dan dengan siapa mereka berkomunikasi. ${ }^{10}$ Selain itu, jalinan komunikasi antarpribadi yang dibangun akan menolong seseorang dalam memahami kenyataan dunia sekitarnya sehingga ia dapat mengetahui dan menguji kebenaran kesan-kesan dan pengertian yang ditangkap oleh indranya. Hal ini terjadi karena melalui proses komunikasi antarpribadi seseorang dapat melakukan pembandingan kesan-kesan dan pengertian dari orang lain tentang realita yang sama (social comparison).

Proses validasi seperti ini dapat terjadi hanya melalui komunikasi antarpribadi. Manfaat komunikasi antarpribadi yang lain adalah pencapaian kesehatan mental seseorang yang terbentuk melalui kualitas komunikasi atau hubungan kita dengan orang lain, secara khusus bila mitra kelompok pribadi terdiri dari insan yang memiliki signifikansi (significant figures) dalam hidup seseorang. Jika mitra komunikasi terdiri dari pribadi-pribadi yang antusias, bijaksana, berpikir positif, jujur, mengutamakan kebahagiaan, altruist maka perkembangan kesehatan mental seseorang akan dibentuk oleh komunikasi antarpribadi kelompok tersebut. Sebaliknya, bila komunikasi antarpersonal dengan orang yang diliputi berbagai masalah, maka akibatnya kesehatan mental seseorang berada dalam kondisi menderita, depresi, merasa sedih, cemas, dan frustasi, bahkan mungkin juga mengarah penderitaan fisik (psikosomatik). ${ }^{11}$

Setiap kelompok generasi di atas akan merasa bahagia dalam kehidupannya, bila ia mendapat kredensi sosial, oleh karena itu melalui proses komunikasi antarpibadi tentu saja dia mendapatkan konfirmasi dari orang lain, ${ }^{12}$ yakni pengakuan berupa tanggapan dari orang lain yang menunjukkan bahwa dirinya normal, sehat, dan berharga, begitupun sebaliknya. Semua itu hanya dapat diperoleh lewat komunikasi antarpribadi atau komunikasi dengan orang lain, khususnya dalam lingkup keluarga, sebagai lembaga sosial pertama yang mumpuni menanamkan kecakapan berkomunikasi dalam kehidupan.

Dalam era konsumerisme dengan lahirnya platform online marketing, mungkin orangtua bisa terjebak menilai kebahagiaan bila membelikan gawai dan berbagai produk aplikasi kepada anak-anak seolah-olah merupakan cara menyenangkan anakanak. Pada dasarnya paham ini keliru dan memang dapat menjadi jebakan bagi orangtua, karena kenikmatan berbeda dari kebahagiaan. Kesenangan memakai gawai memang nikmat, namun selanjutnya mengubah berbagai tatanan kehidupan sosial menjadi buruk, penggunaan aplikasi yang berlebihan mengorbankan prioritas pekerjaan

${ }^{10}$ A. Supratiknya, Komunikasi Antarpribadi, Tinjauan Psikoloogis, (Yogyakarta: Penerbit Kanisius, 1995). 9-10

11Ibid.

${ }^{12}$ Rannu Sanderan, "Stratifikasi Sosial, Kepemimpinan Tradisional dalam Dinamika Demokrasi Modern" Jurnal Lembaga STAKN Toraja, 2016. 
yang seharusnya diutamakan, termasuk dampak selanjutnya yang kurang baik bagi pola komunikasi antarpribadi. Akan tetapi dalam kenyataan hidup sehari-hari, walaupun anak-anak sudah diberi alat komunikasi (tablet, smatphone, laptop) dengan dukungan berbagai aplikasi dan jaringan internet yang kuat namun ternyata tidak jarang anakanak remaja masih mengeluh dan merasa tidak diperhatikan orangtua mereka, dan juga sebaliknya banyak pula orangtua yang mengeluh karena tidak didengarkan lagi oleh anaknya.

Keluhan-keluhan semacam ini mengindikasikan bahwa hubungan antara anak dan orangtua yang seharusnya amat dekat kini seolah dijauhkan oleh produk komunikasi era 4.0., dan selanjutnya bagaimana artificial intelligence melahirkan dehumanisasi serta mengarahkan pengguna produk tersebut menjauh dari dunia nyata termasuk menjauhi hangatnya hubungan karib. ${ }^{13}$ Sama halnya dengan masalah yang dialami pasangan suami istri, munculnya berbagai keluhan personal, tidak lain disebabkan karena komunikasi antarpribadi yang buruk. Lebih daripada itu salah satu akibat dari komunikasi yang buruk dalam keluarga adalah menimbulkan kenakalan remaja yang disebabkan karena tidak adanya perhatian dan curahan kasih sayang dari orang tua mereka. ${ }^{14}$ Orangtua dengan kesibukan masing-masing memberi contoh individualistik bagi anak-anak mereka, karena waktu untuk berkomunikasi di rumah dihabiska dengan kesibukan masing-masing berinteraksi dan memeriksa status di dunia medsos. Kesalahan mengelola waktu ketika sedang bersama dengan keluarga, menyebabkan tidak adanya komunikasi antara orangtua dengan anak, akibatnya banyak anak-anak lebih banyak juga menghabiskan waktu berselancar sendiri di internet tanpa kontrol dari orang tua. Secara fisik, dalam keluarga mereka dekat, namun akibat kesibukan di dunia maya, malah membuat mereka berjauhan. Padahal jika perilaku seperti ini terusmenerus berlangsung dalam waktu yang lama, maka tidak jarang akan menimbulkan kenakala remaja. Oleh karena itu jika orang tua menghendaki masa depan yang lebih baik untuk anak-anak mereka, maka pola komunikasi antara orang tua dengan anak perlu diperbaiki.

\section{Kasih sebagai roh komunikasi interpersonal}

Kehidupan keluarga Kristen, secara teologis melihat kebutuhan kasih sayang antaranggota keluarga sebagai nilai mendasar karena hal itu sendiri merupakan refleksi dari kasih Kristus. Namun tidak dapat dipungkiri bahwa dalam kenyataannya, pernyataan kasih sayang tersebut seringkali mengalami kendala. Kathleen Liwidjaya mengatakan: "dalam hubungan suami isteri, bila cinta menemui kegagalan, maka perkawinan akan hancur yang menyebabkan frustasinya suami isteri, yang berakibat

${ }^{13}$ Nicholas A. Christakis, "How Ai Will Rewire Us," Atlantic 323, no. 3 (April 2019): 10-13.

${ }^{14}$ Kathleen H. Liwidjaya dan Yonathan Kuntaraf., Komunikasi Keluarga, (Bandung: Indonesia Publishing House, 1999), 200. 
buruk juga kepada anak-anak."15 Kegagalan cinta pertama-tama terjadi dalam kegagalan mengomunikasikannya secara personal, sehingga bila akar masalah ini tidak diselesaikan maka timbul akibat domino lainnya. Komunikasi cinta dua orang yang berlangsung dalam dunia maya, karena tuntutan pekerjaan atau studi, umumnya mengakibatkan konflik personal dan interpersoal. ${ }^{16}$ Jadi, komunikasi kasih sayang dan cinta memang membutuhkan kecakapan untuk mengartikulasikannya tanpa jarak, khususnya secara fisik indrawi. Sehingga cinta yang dikomunikasikan secara personal dengan sukses adalah awal kebahagiaan. Ini berarti bahwa berbagai bentuk pernyataan kasih sayang lewat komunikasi antarpribadi dalam keluarga sangat penting dibangun karena itu akan menumbuhkan kebahagiaan dalam keluarga tersebut bahkan dapat juga menularkan kebahagiaan bagi orang lain.

Bahkan lebih lanjut lagi, komunikasi antarpribadi yang baik juga merupakan solusi dalam menyelesaikan berbagai masalah yang timbul dalam kehidupan keluarga rumah tangga masa kini. Karena lewat komunikasi antaranggota keluarga yang efektif, kecurigaan ataupun pikiran-pikiran yang negatif terhadap suami atau isteri yang kadang muncul akan terjawab. Komunikasi antarpribadi yang efektif antara suami dan isteri sebagai orangtua akan berdampak positif juga bagi hubungan mereka terhadap anakanak. Itu sebabnya komunikasi antarpribadi yang efektif dalam lingkup keluarga amat penting bukan hanya bagi suami dan isteri, melainkan juga penting bagi anak-anak yang membutuhkan sentuhan kasih sayang orangtua. Sentuhan indrawi inilah yang menjadi akses terbaik dalam menanamkan nilai dan prinsip hidup generasi $\mathrm{Y}, \mathrm{Z}$ dan alpha.

Komunikasi antara suami dengan isteri, berawal dari komunikasi antara seorang laki-laki dewasa dengan seorang perempuan dewasa yang kemudian dipersatukan dalam pernikahan kudus sehingga keduanya menjadi satu daging (Mat. 19:5) dan inilah yang disebut sebagai sepasang suami-isteri. Bahkan lebih lanjut, dalam menghadapi tantangan perubahan sosial 5.0 ke depan, maka komunikasi interpersonal dalam pernikahan makin menuntut adanya komitmen, seperti kata Norman Wright mengatakan bahwa: "A Christian marriage can also be described as a total commitment of Jesus Christ and to each other"17. Hal ini menyatakan bahwa setelah pasangan suami istri tersebut diberkati maka mereka terbilang sebagai satu keluarga Kristen yang baru, yang di dalamnya terbangun sebuah komitmen penuh untuk hidup bersama selamanya, saling mengasihi dan menerima apa adanya, dan secara kokoh berlandas pada kasih Yesus Kristus. Ini berarti pula bahwa seorang suami harus mampu mengetahui dan memahami perbedaaan sifat dan karakter sang isteri, begitupun sebaliknya. Komunikasi antar-

15Ibid., 37

16Saadatun Nisa and Praesti Sedjo, "KONFLIK PACARAN JARAK JAUH PADA INDIVIDU DEWASA MUDA" 3, no. 2 (2010): 7.

${ }^{17}$ Wright, H Norman., The Family that Listens, (Printed in the United States of America: Victor Books, Fourth printing, 1981), 14 
pribadi yang baik akan memampukan suami istri saling mengetahui dan memahami pasangannya dan pembudayaan komunikasi interpersonal dapat membuat seseorang benar-benar terampil mengomunikasikan kasih dan cinta dengan tepat terhadap pasangannya.

Sama halnya dengan komunikasi antara suami dengan istri, betapa pentingnya komunikasi antara orangtua dengan anak disetting agar anak memiliki harga diri yang tinggi, dimana terbukti bahwa kurangnya komunikasi antara orangtua dengan anak telah menyebabkan harga diri yang rendah di kalangan anak remaja. ${ }^{18}$ Sebab ternyata harga diri yang rendah ini turut menjadi awal penyebab mereka terjerumus ke dalam kenakalan remaja. Padahal memanfaatkan waktu bersama untuk berdialog melatih kecakapan komunikasi interpersonal dengan anak justru jauh lebih bermanfaat, memupuk kebahagiaan dalam keluarga serta kesempatan menanamkan nilai serta prinsip Kristiani bagi anak. Dengan sendirinya seorang anak yang tumbuh dalam komunikasi antarpribadi yang sehat akan sanggup tampil menunjukkan karakter kristiani dalam era disrupsi.

Pada dasarnya komunikasi adalah kebutuhan vital sang anak, sehingga dengan komunikasi yang baik, disiplin dapat dipertahankan dan nilai-nilai yang baik dapat dibentuk. Sekalipun banyak orangtua merasa bahwa perbedaan pendapat antargenerasi adalah hal yang tidak bisa dihindarkan, namun komunikasi yang baik antara orangtua dengan anak menunjukkan adanya penerimaan orangtua kepadanya. Melalui komunikasi antarpibadi, orang tua dapat mengungkapkan kasihnya pada anak-anaknya, menerima anaknya dalam keadaan apapun, karena jika seorang anak merasa bahwa dia dicintai atau diterima, maka ia akan bebas untuk berpikir tentang perubahan dirinya, lalu bangga menjadi diri sendiri, sehingga seiring perubahan waktu ia memiliki kemampuan dan kreatifitas. Karena itu, sesungguhnya perasaan diri diterima akan menyanggupkan seorang anak untuk mencapai potensinya yang tertinggi. ${ }^{19}$

Mengomunikasikan penerimaan kepada anak, akan jauh lebih baik bila menggunakan komunikasi indrawi seperti; sentuhan dan gerak memeluk, sikap mendekati, membelai, serta tatapan mata dan perilaku keteladanan yang sesuai dengan kata-kata. Namun hal sederhana dan paling penting di sini adalah bagaimana orangtua siap mendengarkan sang anak, semua orangtua dapat melakukan hal ini. Seperti ungkapan Kathleen, "Bila Anda ingin menunjukkan penerimaan bagi anak Anda, maka Anda harus siap untuk mendengar kepada anak Anda". ${ }^{20}$ Jadi, bila selama ini banyak orangtua prihatin terhadap masalah anak-anak mereka, maka jawaban terhadap masalah mereka adalah: 'Ajukanlah pertanyaan' dan saling bercakap-cakaplah.

Mendengar dengan aktif kepada anak memberi pengertian memiliki keinginan dan siap memberi waktu untuk mendengar, siap untuk memberikan pertolongan, dan siap

18Ibid., 201

19Ibid., 206

20Ibid., 207 
menerima perasaan anak sekalipun berbeda dengan yang diharapkan. Oleh karena, pada dasarnya perasaan anak itu selalu berubah dari waktu ke waktu khususnya dalam era disrupsi sekarang ini. Oleh karena itu, orangtua amat perlu untuk memberi kepercayaan kepada anak dalam rangka melatih keterampilan mengendalikan perasaannya dan belajar bijaksana menyelesaikan problemnya sendiri dengan aktif dan terus-menerus melatih komunikasi interpersonal mereka.

Kenyataan revolusi industri 4.0 dengan segala produk dan tantangan yang diperhadap-kan bagi orangtua Kristen membuat pemerhati pelayanan gereja dan para pemimpin Kristen untuk makin giat membimbing jemaat agar mulai mengarusutamakan komunikasi interpersonal dalam keluarga Kristen. Masyarakat sehat diawali dengan komunikasi yang sehat dalam keluarga. Jadi, bila pembudayaan komunikasi interpersonal cukup intens dan kuat dalam keluarga maka perkembangan anak-anak tidak dikuatirkan karena mereka telah memiliki fondasi, identitas dan kebanggaan untuk menjadi diri sendiri. Terlebih lagi bila orangtua telah menanamkan komunikasi interpersonal sebagai budaya keluarga sejak anak-anak masih kecil.

\section{Kesimpulan}

Dapat disimpulkan bahwa komunikasi antarpribadi yang dimaksud dalam tulisan ini bukanlah bentuk verbal, namun juga harus dalam bentuk sentuhan fisik. Bagi generasi Z, yang diperlukan adalah telinga yang mendengarkan dan pertanyaan-pertanyaan yang dapat membantu mereka memikirkan masalahnya sendiri melalui perkapan langsung. Pertanyaan menjadi gerbang komunikasi interpersonal orangtua mengajar anak-anak memikirkan persoalan mereka sendiri dan bersama bercakap-cakap mencari jawaban, sekaligus orangtua memberikan kepercayaan dan menunjukkan perhatian terhadap apa yang harus dikatakan oleh anak-anak. Era 4.0 dapat memberikan berbagai jawaban daan kebutuhan manusia kecuali kasih sayang dalam sentuhan fisik. Sentuhan fisik akan membantu anak menumbuhkan suatu konsep diri yang positif, humanis dan menghargai diri sendiri serta orang lain. Akhirnya, di era 4.0 ini, sering mengambil waktu khusus, duduk bersama dan bertanya langsung kepada anak serta setia mendengar merupakan pintu masuk untuk intens melatih kecakapan komunikasi interpersonal mereka.

\section{Referensi}

Agustin, Sari Monik Agustin. "Digital Body: Horcrux of Extended Self in Post-Human Era," Jurnal Komunikasi Indonesia (January 2019): 204-214-214.

"Aktualisasi Pelayanan Karunia Di Era Digital | Siahaan | EPIGRAPHE: Jurnal Teologi Dan Pelayanan Kristiani." Accessed June 12, 2019.

http://www.stttorsina.ac.id/jurnal/index.php/epigraphe/article/view/7/2.

Ananta, Unggul Y. Merajut Mimpi Pemuda Berdaulat Hari Esok (Sebuah Mimpi

Brake, Andrew. Hidup Bijak di Dunia Bodoh, Mengali Sumber Hikmat Sejati dari Kitab

Amsal, (Bandung: Kalam Hidup, 2015)

Christakis, Nicholas A. “How Ai Will Rewire Us," Atlantic 323, no. 3 (April 2019) 
Membangun Pemuda Milenial Menuju Indonesia Berdaulat). Yogyakarta: Diandra Kreatif, 2018.

Darmaputera, Eka. Pergulatan Kehadiran Kristen di Indonesia. Jakarta: BPK Gunung Mulia, 2001.

Kosala, Anbiya Senapati. "Extreme Work" Di Era Revolusi Industri 4.0. Samarinda, Ebook. 2018.

Kuntaraf, Kathleen H. Liwidjaya dan Yonathan Kuntaraf., Komunikasi Keluarga. Bandung: Indonesia Publishing House, 1999.

Nisa, Saadatun and Praesti Sedjo. "KONFLIK PACARAN JARAK JAUH PADA INDIVIDU DEWASA MUDA" 3, no. 2 (2010)

Sanderan, Rannu. "Exemplary, Menemukan Kunci Pendidikan Iman bagi Anak dalam Keluarga dan Pembelajaran Agama di Sekolah,” Jurnal Arrang: STAKN Toraja, 2016.

Shelley, Mack, and Klaus Krippendorff. "Content Analysis: An Introduction to Its Methodology." Journal of the American Statistical Association 79, no. 385 (March 1984): 240. https://doi.org/10.2307/2288384

Supratiknya, A., Komunikasi Antarpribadi, Tinjauan Psikologis. Yogyakarta: Penerbit Kanisius, 1995.

Tim Penyusun Kamus Pusat Pengembangan Bahasa Indonesia Departemen pendidikan dan Kebudayaan, Kamus Besar Bahasa Indonesia. Jakarta: Balai Pustaka, 1998.

Triningtyas, Diana A. Sex Education, Magetan: CV. AE Media Grafika, 2017

Wright, H Norman.The Family that Listens. Victor Books, Fourth printing, 1981.

Wahlroos, Sven.,Komunikasi Keluarga: Panduan menuju kesehatan emosional dan hubungan antarpribadi yang lebih harmonis (Terjemahan). Jakarta: BPK-Gunung Mulia, 1999. 